\title{
Two new Paleozoic Asteroidea (Echinodermata) and their taxonomic and evolutionary significance
}

\author{
Daniel B. Blake, ${ }^{1}$ and Joseph Koniecki ${ }^{2}$ \\ ${ }^{1}$ Department of Geology, University of Illinois, 506 W. Springfield, Champaign, Illinois 61820, USA 〈dblake@illinois.edu〉 \\ ${ }^{2} 3529$ E. Joy Rd., Ann Arbor, Michigan 48105, USA 〈paleojk@gmail.com〉
}

\begin{abstract}
Sertulaster keslingi new genus new species (Palaeasteridae) and Delicaster hotchkissi new species (Permasteridae) are asteroid echinoderms described, respectively, from the Ordovician and Carboniferous of eastern North America. The new genus and species help to document diversity within taxa of lower rank. S. keslingi is similar to the Early Ordovician Eriaster Blake and Guensburg, 2005 but exhibits less differentiation of the skeletal elements from beyond the ambulacral column, that of the so-called extraxial skeleton, whereas the comparatively robust construction of Delicaster hotchkissi clearly departs from that of the type species, D. enigmaticus (Kesling, 1967). Small sample sizes and incomplete exposure of available specimens illustrate ambiguities typically encountered in the study of fossil asteroids.
\end{abstract}

UUID: http://zoobank.org/fb44075c-396b-4f95-b997-29cdf3c4f3c1

\section{Introduction}

Ambulacral expression is essential to the interpretation of echinoderms of all ages (e.g., Mooi and David, 1998, 2000, 2008); vaulting of the ambulacral series toward the dorsal surfaces to form the ambulacral furrow provides an explicitly and implicitly widely used basal apomorphy of the class Asteroidea; the vaulting, however, largely obscures the crucial ambulacral morphology of both extant and fossil asteroids.

The asteroid skeleton of comparatively small and articulated rather than fused elements is particularly vulnerable to taphonomic disruption, collapse, and complete destruction during fossilization processes, and that together with the subsequent damage during outcrop exposure leads to a scanty fossil record. Arguably largely because of these issues, earlier viewpoints on classification and phylogeny of Paleozoic Asterozoa have differed significantly, and consensus has been slow to emerge (e.g., Spencer, 1914-1940, and references therein; Spencer, 1951; Spencer and Wright, 1966; Kesling, 1969; McKnight, 1975; Shackleton, 2005; Blake, 2013, 2014, 2018; Blake and Guensburg, 2015).

Spencer and Wright (1966, p. 9) began to address difficulties in recognizing a three-fold subdivision of the asterozoan skeleton, the subdivisions termed "axial," "adaxial," and "extraxial"; "axial" and "adaxial" correspond to traditional "ambulacral" and "adambulacral" usages whereas the combination of the remainder of the skeleton into a single "extraxial" category departed from the traditional. Hotchkiss (1993) applied the Spencer and Wright (1966) skeletal classification in a study of an ophiuroid, and although not emphasizing the term "adaxial," David and Mooi (1996, 1998), Mooi et al. (1994), and Mooi and David (1998, 2000, 2008) discussed the broad extraxial skeletal variability that accompanied the evolution of many echinoderms. Variability of the extraxial skeleton contrasts with the relative stability of the axial and adaxial skeletons, the stability adding to obscure positioning within the asteroid furrow in limiting their emphasis in taxonomy, although at the same time providing opportunity for revised approaches of interpretation. An axial-extraaxial emphasis was incorporated in a study of Triassic asteroids (Blake and Hagdorn, 2003, p. 33), Villier et al. (2017) revisited the differentiation of the post-Paleozoic Asteroidea with a phylogenetic analysis founded on a select group of well-preserved Paleozoic and Mesozoic exemplars, and taxonomic concepts of the Paleozoic Asterozoa were revisited by Blake (2018), arguing that some evaluations of Villier et al. (2017) anticipated and indirectly supported aspects of the Blake (2018) taxonomy.

Recent studies of many surviving invertebrate taxa based on molecular approaches, including those of crown-group Asteroidea, have led to significant reinterpretation of phylogenetic histories and taxonomy, but such approaches are not available for stem groups, and because of the scanty fossil record, any attempt at comprehensive morphologically based phylogenetic reconstruction for the Paleozoic asterozoan fauna at the current state of knowledge is seen as severely compromised (Blake, 2018). Lacking molecular and more comprehensive morphologic data, both generic and familial interpretations such as those discussed here are important to the development and testing of classifications and phylogenetic reconstructions. Sertulaster keslingi new genus new species (Figs. 1.1-1.6, 2.1-2.4) is compared with Eriaster ibexensis Blake and Guensburg, 2005 (Figs. 1.7, 2.5, 2.6), and Delicaster hotchkissi new species (Figs. 3, 4.1-4.7) is compared with Delicaster enigmaticus (Kesling, 1967) (Fig. 4.8-4.10), the new taxa 
helping to document their families, respectively, the Permasteridae and Palaeasteridae, both reviewed by Blake (2018).

\section{Materials}

Repositories and institutional abbreviations. - The four specimens of Sertulaster keslingi are housed in the collections of the University of Michigan Museum of Paleontology (UMMP); the only Delicaster hotchkissi specimen is at the Yale Peabody Museum (YPM).

\section{Systematic paleontology}

Terminology.-Terminological usage for asterozoans begins with Spencer and Wright (1966). The primary skeleton forms the body wall. The accessory skeleton includes the generally abundant spines, granules, and pedicellariae seated on all primary ossicles except ambulacrals. Axial or ambulacral ossicles form a double series along the axis of the arm and serve as the foundation for the water vascular system. Axials are vaulted to form the ambulacral furrow, and the mouth angle ossicles (MAO) are the proximal-most ossicles of the axial series. Axial ossicles articulate with and are immediately dorsal to the adaxial or adambulacral ossicles. The remainder of the skeleton is extraxial. Marginal ossicles form either a single inferomarginal series or a double inferomarginal plus superomarginal series, one or both positioned near the margin of the asteroid. Abactinal ossicles are above the marginal series. A primary circlet of abactinals can be differentiated on the dorsal disk, and dorsal midarm ossicles can be enlarged and/or otherwise differentiated to form a carinal series. In most asteroids, lateral abactinal series occur adjacent to the midarm carinal series; here, 'lateral' is used as a positional descriptor and does not in itself argue series homology among taxa. A madreporite provides both inlet and outlet of the water vascular system for most asteroids, although it is difficult to locate in many Paleozoic fossils. No, few, or many actinals occur between the inferomarginals and adaxials.

Order Hadrosida Blake, 2018

Family Palaeasteridae Miller, 1889

Diagnosis._-"Disk size small to moderate, moderately thick, arms thickened in cross-section, interbrachia more or less narrowly rounded; arms ranging from triangular and more or less elongate to comparatively short and abruptly tapering. Abactinals varied among taxa. Primary circlet well developed, supplemental ossicles and proximal-most superomarginals can be incorporated into circlet ring. Primary circlet enclosing an area usually of both smaller and larger ossicles. Carinal series differentiated or not, where enlarged, lateral series can be present; distinct transverse series present in some genera. Madreporite where recognized dorsal, partially enclosed by primary circlet. Marginals in two series; ossicular form varied from enlarged and block-like to comparatively delicate, elongate, and subcylindrical. Intermarginals can occur but not recognized in all genera. Axillary enlarged where known, near disk margin. Actinals not known to occur. Accessories varied, spines can be present. Adambulacrals varied, ventral in position, not at arm margins. Mouth area generally poorly known; MAO where known robust, closely fitted around mouth area; buccal slit can be developed; torus can occur" (Blake, 2018, p. 38).

\section{Genus Sertulaster new genus}

Type species.—Sertulaster keslingi $\mathrm{n}$. gen. n. sp., only species.

Diagnosis.—As for the type species, by monotypy.

Etymology.-Latin, diminutive of serta, garland, wreath, recognizing the prominent garland-like primary circlet typical of the Palaeasteridae, including the new genus Sertulaster.

Remarks.-Configuration of the arm cross section (Fig. 2.4), with proportionately large ambulacrals fully dorsal to the adambulacrals, is characteristic of the order Hadrosida (Blake, 2018). Sertulaster is assigned to the Palaeasteridae sensu Blake (2018) based on overall form, including a relatively small, arched disk with narrowly rounded interbrachial angles and elongate triangular arms. In addition, the primary circlet is enlarged, and carinal and marginal expressions are similar to those of other palaeasterids.

\section{Sertulaster keslingi new species \\ Figures 1.1-1.6; 2.1-2.4}

Holotype.-UMMP 74694, the holotype and all three paratypes rest on indurated carbonate blocks, all exposed in dorsal aspect, all appearing only slightly distorted by sediment compaction. Arm taper and apparent terminal ossicles suggest four of the arms are nearly complete, $\mathrm{R} \approx 7-8 \mathrm{~mm} ; \mathrm{r} \approx 2.5 \mathrm{~mm}$.

Paratypes.-UMMP 74695, three complete or nearly complete arms $\mathrm{R} \approx 10-11 \mathrm{~mm}$, incomplete arms $\mathrm{R} \approx 5-6 \mathrm{~mm}, \mathrm{r} \approx 3.5-$ $4 \mathrm{~mm}$; UMMP 74696, only the broken arm appearing nearly complete, $\mathrm{R} \approx 13 \mathrm{~mm}$, incomplete arms $\mathrm{R} \approx 7-12 \mathrm{~mm}, \mathrm{r} \approx$ $5 \mathrm{~mm}$; UMMP $74697, \mathrm{R} \approx 13-15 \mathrm{~mm}$, one nearly complete, only bases remaining of two arms, one with scattered, not clearly recognizable ossicles, $\mathrm{r} \approx 5 \mathrm{~mm}$.

Diagnosis.-Palaeasterid with only five closely spaced dorsal arm ossicular series, these consisting of two superomarginal (SM), two inferomarginal (IM), and one carinal series. Each interbrachium with two proportionately large, upright superomarginal ossicles. Relatively small axillary at disk edge. Primary circlet of 10 ossicles; supernumerary ossicles lacking in circlet; circlet ossicles robust, subelliptical in outline. Interradials inset from radials. Primary circlet enclosing central area of an outer ring of 10 ? larger ossicles, these in turn enclosing two? medial ossicles, the larger ossicles partially separated by closely fitted smaller ossicles.

Occurrences.-The holotype (UMMP 74694) was obtained through purchase, the accompanying locality data sourcing it from the Verulam Formation at the LaFarge Belleville Quarry, near Belleville, Ontario, Canada $\left(44.95744^{\circ} \mathrm{N}, 77.172755^{\circ} \mathrm{W}\right)$. It is not known whether the specimen was collected in situ or from a blast pile. The paratypes (UMMP 74695-74697) were found in the upper Bobcaygeon Formation of Kirkfield, Ontario, 


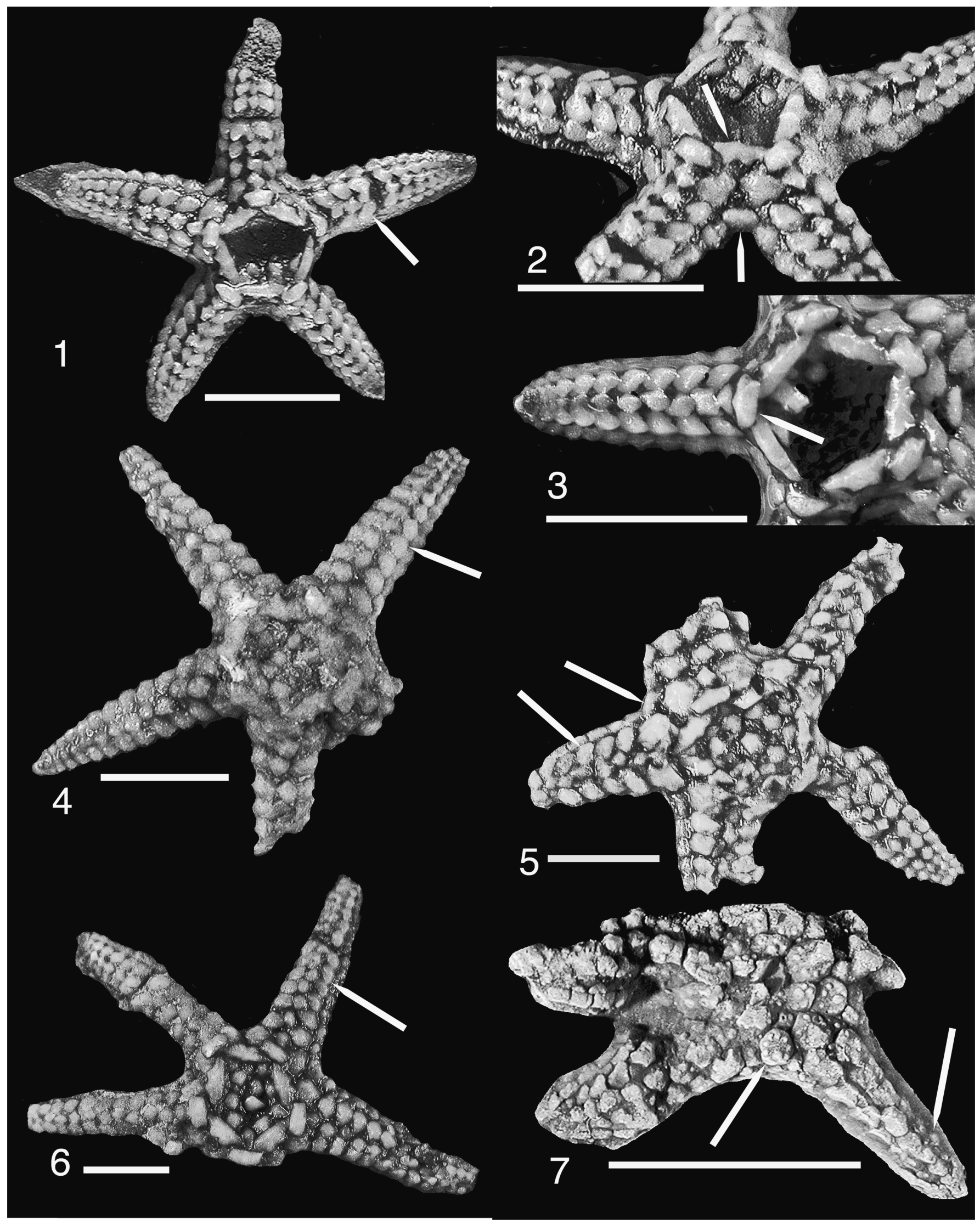

Figure 1. (1-6) Sertulaster keslingi n. gen. n. sp., family Palaeasteridae; specimens wetted to delineate ossicular shapes and arrangements. Surfaces are finely pustulate but enlarged spine bases are lacking. (1-3) Holotype UMMP 74694: (1) complete specimen, central disk ossicles lost or collapsed into disk interior; arrow at superomarginal (SM) series; (2) inclined view, inset primary circlet interradial (upper arrow) abuts two radials, primary circlet does not include supplemental ossicles; the interradial bears two ventrally directed flanges and is separated by two upright disk superomarginals from axillary (lower arrow), which lies between two arm marginal series; no intermarginal series is developed; (3) dorsal aspect, radial (arrow) at head of carinal series. (4) Paratype UMMP 74695, arrow at SM series; (5) paratype UMMP 74696, left arrow at SM series, right arrow at axillary, is beneath enlarged disk SM pair; (6) paratype UMMP 74697, arrow at SM series. (7) Eriaster ibexensis Blake and Guensburg, 2005, is most similar to Sertulaster among known palaeasterid genera; overall view of holotype; primary circlet ossicle (left arrow) is subcircular and pustulate; enlarged carinal series ossicles extend to the arm tip and overlie marginal and intermarginal series (right arrow); see also Figure 2.5, 2.6. Scales bars $=5 \mathrm{~mm}$. 


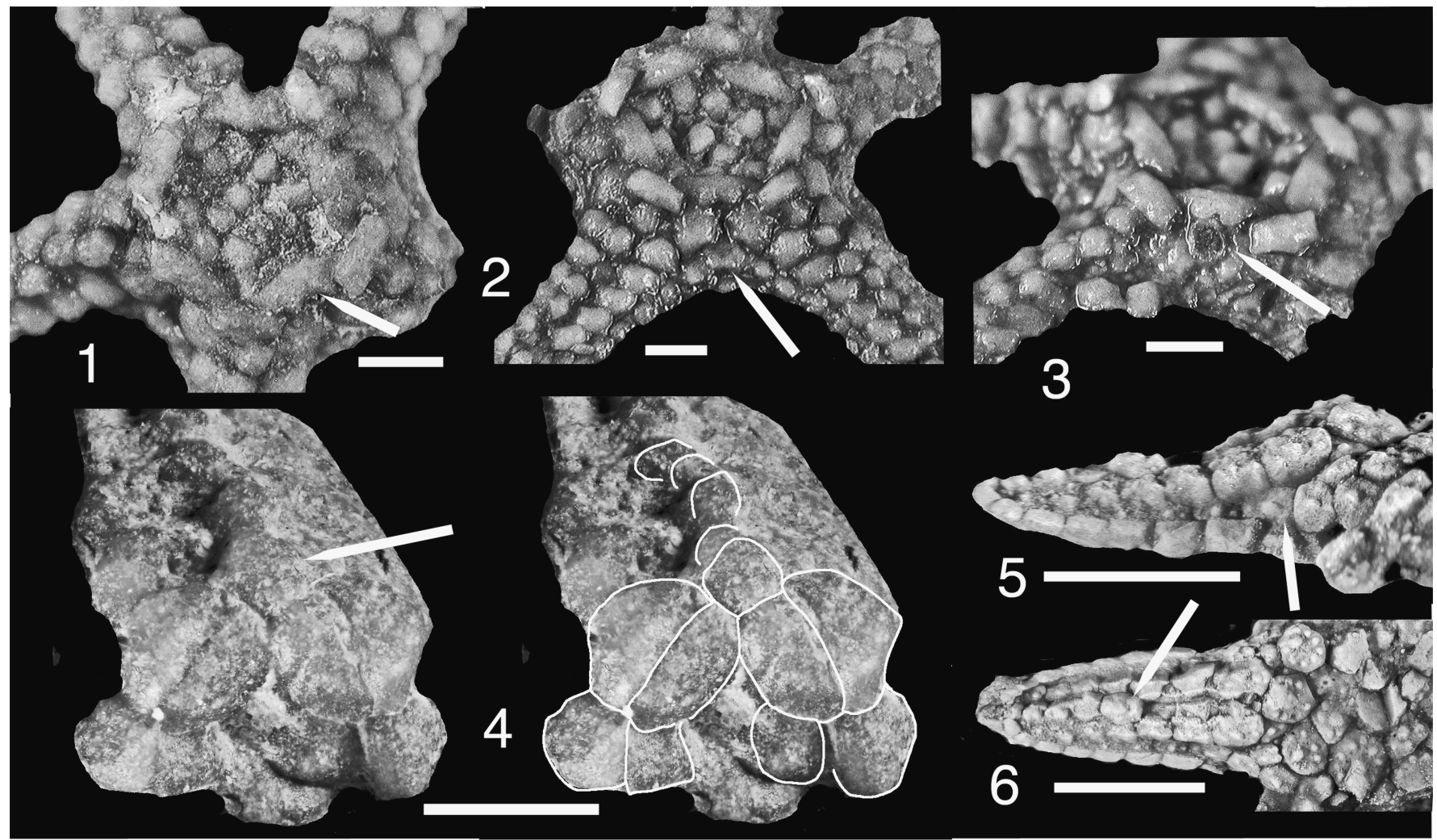

Figure 2. (1-4) Sertulaster keslingi n. gen. n. sp., family Palaeasteridae; (1-3) disk and proximal arm morphology; (1) paratype UMMP 74695, interradial at arrow; $(\mathbf{2}, \mathbf{3})$ paratype UMMP 74697, (2) axillary at arrow, (3) madreporite at arrow; (4) upper right arm of Figure 1.5 in cross section, ossicular outlines to right; carinal (arrow) overlies ambulacral pair, the pair abutting superomarginals (SMs), adambulacrals below; SMs overlie inferomarginals (IMs); a displaced ossicle not a part of the cross section is medial below; (5-6) Eriaster ibexensis Blake and Guensburg, 2005, Field Museum of Natural History FMNH PE 52741, is judged most similar to Sertulaster among known palaeasterids; see also Figure 1.7; (5) intermarginal series (arrow) do not occur in Sertulaster; (6) carinal series missing proximally on arm, proximal-most surviving carinal at arrow. Scale bars $=2 \mathrm{~mm}$.

Canada. The specimens were collected in a small blast pile located near the top of the Kirkfield Quarry, now Kirkfield Lake $\left(44.35632^{\circ} \mathrm{N}, 78.58816^{\circ} \mathrm{W}\right)$. The two formations are part of the Simcoe Group with the Bobcaygeon Formation overlain by the Verulam Formation (Armstrong, 2000). The middle and upper Bobcaygeon and Verulam formations are Late Ordovician (Katian) in age (Brookfield and Brett, 1988; Holland and Patzkowsky, 1996; Sproat et al., 2015).

Description.-Disk subcircular, small relative to arm length, interbrachial angles narrowly rounded, disk vaulted (central portion more or less collapsed into disk in available specimens). Arms elongate, nearly straight-sided but perhaps tapering more abruptly distally. Arm cross section subrectangular, carinal series forming ridge at least proximally. Primary circlet clearly defined, consisting of five radials and five interradials; interradials inset toward disk center from adjacent radials; upper surface of circlet ossicles rounded. Radials approximately rectangular, wider than long, with a low central prominence possibly representing an accessory base. Interradials wider than radials, narrowed termini of interradials probably overlapped by radials; interradial outline interrupted by two small projections or flanges on distal margin of each ossicle, flanges of one interbrachial abutting and partially enclosing madreporite. Primary circlet enclosing ossicles of two size classes: A ring of 10 ? larger ossicles aligned with primary circlet, those proximal to the interradials inset from those proximal to radial ossicles; 2 ? enlarged ossicles within outer ring; smaller ossicles of uncertain number crowded within primary circlet, partially separating outer ring from medial ossicles. Madreporite relatively small, subcircular in outline, beneath and abutting an interbrachial, bordered laterally and ventrally on each side by an enlarged proximal SM.

Abactinals of carinal series ossicles approximately equidimensional; shallow lateral, proximal, and distal facets overlap next-distal carinal and superomarginals, facets enclosing papular? reentrants; more distal carinals also appear to be faceted. Surfaces of carinals and marginals finely postulate, no evidence of accessory granules remaining; central portion of carinals raised to form possible accessory prominence. No abactinal series lateral to carinals recognized.

Carinals and SMs equal in number, or nearly so. Proximal SMs forming dorsal-lateral arm margins, their transverse profiles arched or globular and nearly angular, defining the subrectangular arm cross-sectional outline. In dorsal aspect, SMs elliptical, wider than long, axes inclined distally toward carinal; SMs with edging facets. More proximal SMs larger than carinals, distal SMs and carinals more nearly equal in size, distal SMs less clearly arched than proximal SMs. Disk SMs two in each interbrachium, relatively large as compared to arm SMs and forming sides of arched disk; disk SMs nearly equidimensional, surfaces low arched, finely pustulose. IMs and SMs approximately equal in number, ossicles of the two series appearing locally paired to weakly offset. Although SM series 


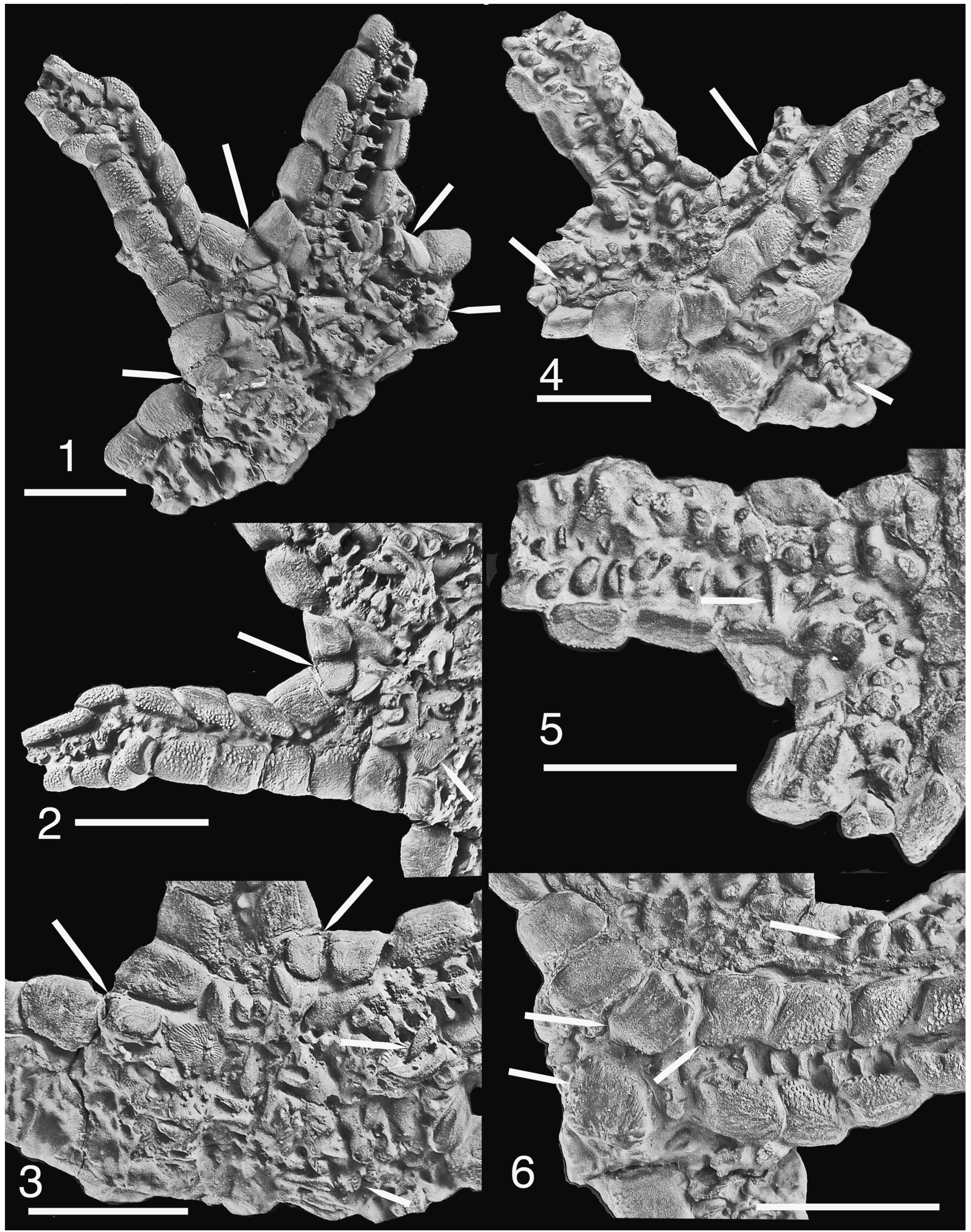

Figure 3. Delicaster hotchkissi n. sp., holotype and only known specimen, YPM IP 238703. The two columns of figures illustrate the opposite surfaces of the single-known specimen, rotated $180^{\circ}$ about the "vertical" axis. Disk ossicles are in disarray although arm intervals are largely intact. (1) The two more complete arms showing primarily marginal and ambulacral ossicular form in dorsal aspect, axillaries at arrows; (2) axillary at left arrow, madreporite immediately beyond axillary at right arrow; (3) disk region, ossicles largely disrupted; axillaries marked by two upper arrows, madreporite near upper left arrow; primary circlet ossicles and adradial face of ambulacral at two lower right arrows; (4) arm to left exposes the ventral surface; arm to right is exposed in dorsal view, folded across the ventral disk surface; adambulacral series at upper right arrow belongs to an arm obscured by the folded arm; lower arrows locate adambulacral ossicles of Figure 4.6, 4.7; (5),upper left arm of Figure 3.4; adambulacral double series along midline is partially obscured and disrupted; adambulacral spines at arrow; (6) proximal interval of folded arm, partially displaced axillaries at arrows to left; small pustules along dorsal edge of marginals (middle arrow); adambulacral series in ventral view, ossicular outlines rectangular with transverse series of spine bases (right arrow). Scale bars $=10 \mathrm{~mm}$. 


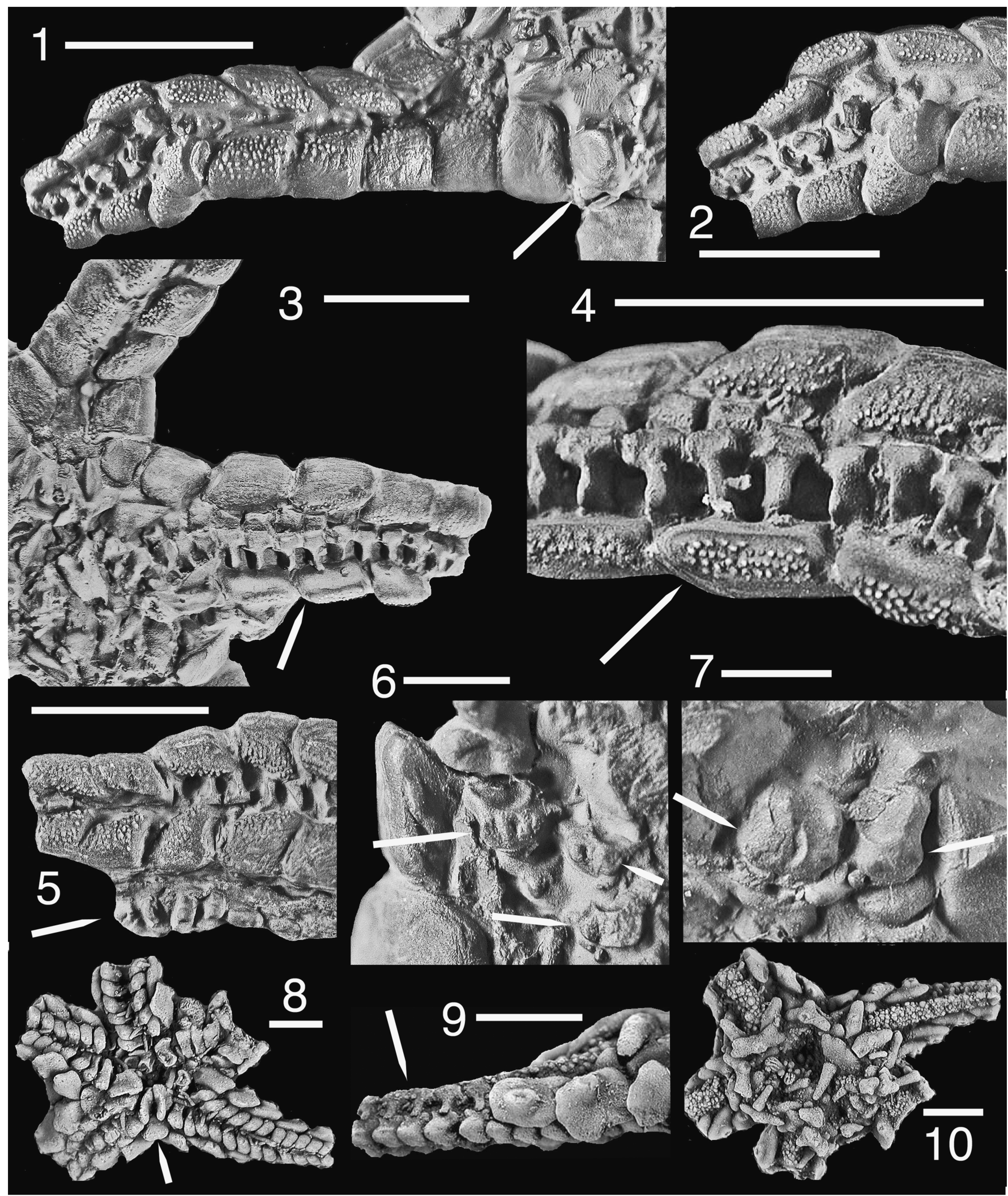

Figure 4. (1-7) Details of Delicaster hotchkissi n. sp., holotype and only known specimen, YPM IP 238703; (1) arm to upper left of Figure 3.1; madreporite above axillary at arrow; more proximal marginals more or less tightly closed over abactinal field, marginal pustules concentrated nearer dorsal edge, broken interval toward left shows appearance of side face of marginal, see also Figure 4.2; (2) tip of arm of Figure 4.1, marginals robust, differing in accessory base as compared to D. enigmaticus, Figure 4.8-4.10; $(\mathbf{3}, \mathbf{4})$ arm to upper right of Figure 3.1 in (4) rotated away from observer about arm axis; arrows identify the same marginal; to orient, see debris on ambulacrals above arrows; notching (i.e., reentrant) along adradial edge of marginals marks positioning of abactinal field, this surface more completely exposed in (3); adradial ambulacral side faces locally exposed across arm midline; (5) portion of proximal arm interval of Figure 3.4, arrows on both figures identifying the same adambulacral series of an obscured arm; ambulacrals of right side exposed, those of left side hidden by marginals; $(\mathbf{6}, 7)$ displaced adambulacrals, arrows marking adambulacral external faces with aligned spine base series and beneath enlarged interadambulacral tissue basins; topographic complexities near the dorsal edges potentially mark positions of adambulacral-ambulacral articular surfaces. Basic adambulacral configuration was enduring through asteroid history, although ambulacrals changed significantly with evolution of podial pores. Adambulacral position marked by lower left and lower right arrows, respectively, of Figure 3.4; (8-10) Delicaster enigmaticus (Kesling, 1967), UMMP 54262; (8) ventral aspect, axillary (arrow) distal to mouth angle pair and adjacent to marginals, these in side view of (9); (9) arm in side view, disk to right; large, plate-like marginals with central spine base are unlike marginals of D. hotchkissi. Hammer-shaped ambulacrals (arrow) are similar to those of $D$. hotchkissi; (10) dorsal ossicles of disk and arm largely intact, unlike corresponding ossicles of the D. hotchkissi specimen. (1-5) Scale bars $=10 \mathrm{~mm} ;(\mathbf{6}-\mathbf{1 0}) \mathrm{scale}$ bars $=3 \mathrm{~mm}$. 
now locally inset on IM series of available specimens, sediment compaction appears to have displaced an upright and aligned life configuration. Lateral surfaces of IMs low arched. Corners of some adjacent marginal series ossicles appear indented for papular pores. Disk IMs confined to ambital edge; weakly enlarged axillary visible in some interbrachia. Intermarginals not developed. Small apparent terminal preserved at several arm tips.

Ambulacral and adambulacral data available only at proximal side of one medial arm cross section (Fig. 2.4), the corresponding distal side poorly preserved. Ossicles at the exposed cross-sectional surface were compacted together and partially fused, obscuring ossicular boundaries. Marginals of the two series forming upright angular arm margins; carinal series forming dorsal-midarm prominence. Ambulacrals small, subrectangular, fully dorsal on adambulacrals; podial pores appear to be lacking. Adambulacrals approximately square in proximal and distal outlines. Adambulacrals directly abut IMs; arm actinals lacking. Carinal and marginal surfaces finely postulate. Some fine ossicular debris is suggestive of accessory ossicles but no clearly recognizable examples remain. Ventral disk data unavailable.

Etymology.-The species name recognizes the many contributions of Robert V. Kesling to paleontology, here in particular to the understanding of ancient asterozoans and other echinoderms.

Remarks.-All available specimens are exposed in dorsal aspect; data on the ventral surface and disk interior are lacking. Among palaeasterids, Sertulaster is most like Eriaster Blake and Guensburg, 2005 (Figs. 1.7, 2.5, 2.6); in the original description of the latter, ossicles adjacent to the carinal series were interpreted as lateral abactinals; these are now reinterpreted as superomarginals based on similarities among palaeasterid genera (Blake, 2018). Most genera of the Palaeasteridae sensu Blake (2018) are known from comparatively large specimens with many extraxial ossicles, these typically not tightly abutted, although extraxials are closely fitted in both Sertulaster and Eriaster. The single and incomplete known specimen of Eriaster is similar in size to UMMP 74694 and smaller than the other three available Sertulaster specimens. Unlike Sertulaster, intermarginal series occur between the marginal series in Eriaster (Fig. 2.6, 2.7).

Extraxial marginals and carinals of Eriaster differ in shape from those of Sertulasterias, in part in that they are flatter and more plate-like than those of the latter; only those of Eriaster are strongly pustulose. The area within the primary circlet of Eriaster is occupied by proportionately larger ossicles rather than the mixed suite of large and small found in Sertulasterias. The arm cross section (Fig. 2.4) demonstrates absence of arm actinals in Sertulaster, as further argued by presence of comparatively narrow arms. The mouth region is not available for Sertulaster, incomplete for Eriaster.

Order Kermasida Blake, 2018

Family Permasteridae Blake, 2018
Diagnosis._- "Disk relatively small, arms elongate, slender, triangular to parallel-sided. Abactinals small to enlarged. Primary circlet ossicles enlarged relative to adjacent ossicles; supplemental ossicles in addition to radials and interradials present; primary circlet enclosing distinct central area of smaller ossicles. Abactinal arm skeleton consisting either of carinal series with few or no lateral-abactinal series ossicles; these series where recognized more or less irregular; or carinal series absent and arm abactinals are small plates of uncertain arrangement. Madreporite near primary circlet. Carinals abutted or separated longitudinally on arm. Relative sizes and proportions of marginals, axillary, and adambulacrals varied where known. Marginals in one series; ossicles varied from robust and block-like to upright and plate-like. Axillaries where known varied from narrow, upright, extending to disk margin; to small, granular, and apparently inset from disk margin. Actinals not occurring on arms; small ossicles on disks of some specimens might represent actinals. Extraxial ossicles typically more or less finely pustular; a single enlarged spine base occurs on some ossicles. Data on ambulacrals limited because of small size and usual enclosure by extraxials; where known, ambulacrals small, upright; dorsal podial pores can occur. Adambulacrals broad or comparatively narrow; if broad, adambulacrals extend to arm margin, bear ventral-spine fringe; otherwise inset from arm margin; preservation of different specimens suggests some positional expressions might have varied with life activities. Disk adambulacrals, where known, can be expanded to form a significant part of ventral disk surface. MAO sizes small to moderate, proportions correlated with sizes of axillary, disk adambulacrals" (Blake, 2018, p. 47).

Genus Delicaster Blake and Elliott, 2003

Type species.-Delicaster enigmaticus (Kesling, 1967), from the Paint Creek Formation, St. Claire Co., Illinois.

Diagnosis.-Form stellate, arms rectangular in transverse outline. Primary circlet and supplemental circlet ossicles wide, rectangular, somewhat irregular in form; enlarged spine base occurs on circlet ossicles of $D$. enigmaticus, not recognized in D. hotchkissi n. sp. Abactinal skeleton of arms where known of small granular platelets; carinal series not developed. Madreporite where known dorsal, near primary circlet. Marginals plate-like, rectangular, upright, aligned parallel to arm length; one prominent spine base present or lacking; marginal dorsal edging of fine pustules present or lacking. Adambulacrals near arm margin, or slightly inset. Axillary similar in size to adjacent marginals, triangular and appearing slightly inset from marginal series onto ventral disk surface or ovate to curvilinear rhombic and aligned with marginal series at disk edge. Actinals not recognized. Adambulacrals robust, rectangular; disk adambulacrals enlarged where known. Smaller spines, spine bases on adambulacrals. Ambulacrals T-shaped, widening at arm midline articulation; large podial pores present, enlarged flanges for articular tissues extending to adambulacrals absent. MAO pair where known upright, comparatively narrow, dilated medially; circumorals where known robust, upright, forked as to partially 
enclose a proximal tube foot; dorsal ossicular shape appearing to allow ample space for an ampulla.

Remarks.-Diagnosis emended from Blake (2018). Kesling (1967) described the new species Neopalaeaster enigmaticus, later recognized as the type species of Delicaster by Blake and Elliott (2003); the genus was revisited by Villier et al. (2017) and Blake (2018).

\section{Delicaster hotchkissi new species}

Figures 3; 4.1-4.6

Holotype.-Holotype and only known specimen, YPM IP 238703, consists of the disk, most of three arms, and the proximal portions of the remaining two arms. The dorsal disk surface, although exposed, is largely collapsed, and ossicles are dislocated with both their original shapes and arrangement largely lost. The madreporite is exposed. One arm is folded down and across the ventral disk surface, obscuring the mouth frame area but exposing the dorsal surface of the arm. One arm is exposed in ventral aspect; it is not well preserved. Ossicles, especially of the arm interiors, are displaced and ossicular exposure is limited, but preservation of exposed surfaces is excellent. The disk appears to have been somewhat flattened and expanded in preservation, the estimated radius as preserved approximately $12 \mathrm{~mm}$; arm radii as preserved from disk edges estimated approximately $30 \mathrm{~mm}, 25 \mathrm{~mm}, 22 \mathrm{~mm}, 8 \mathrm{~mm}$, and $5 \mathrm{~mm}$. Taper suggests the longest remaining arm interval is nearly complete.

Diagnosis.-Species of Delicaster in which marginals are thickened and robust, the distal edges overlapping the next distal marginal. Dorsal edges of marginals uniformly pustulose, side surfaces lacking pustules; enlarged accessory bases not developed. Axillary ovate, subdorsal.

Occurrence.-Available locality data for the only know specimen of Delicaster hotchkissi (YPM 238703) are limited. The specimen was recovered from the Pennsylvanian Canyon Series, Graford Group, the shale above the Willow Point Limestone member; Bridgeport Clay Pit, Wise County, Texas.

Description.-Disk relatively small, interbrachial angles narrowly rounded; disk low, not vaulted and rounded. Arms elongate, straight-sided, taper gradual; arms low, rectangular in cross section. Surface of disk exposing disrupted and displaced larger ossicles, including elongate, subrectangular apparent primary circlet ossicles that lack accessory bases and pustules. Madreporite dorsal, ovate, surface bearing radiating ridges and grooves. No arm abactinal ossicles recognized. Marginal ossicles in single series; marginals robust, plate-like in side view, approximately quarter-circular in transverse section, each overlapping the edge of the next more-distal ossicle; tissue indentations distinct. Dorsally directed marginal surfaces postulate, pustules mostly circular in outline, some radially directed pustules elongate, pustule field gradually terminating ventrally, remainder of ossicular surface smooth. Enlarged marginal spines, spine bases absent; granules not recognized. Adradial ventral edge of marginal abutting upright abradial sides of adambulacrals. Axillary ovate, broadest dorsally, dorsal edge rounded, ossicle tapering ventrally to a pointed tip, tip aligned at approximate ventral edge of marginals; sides of lower portion of ossicle abutting marginals; overall axillary shape and local ossicular arrangement suggesting a subdorsal axillary position. Ambulacrals bilateral, hammer-shaped; 'heads' of hammers abutted longitudinally, interambulacral contacts subcircular; 'handles' of hammers rod-like, separating podial pores and enlarged interior potential ampullar basins. Adambulacrals rectangular in outline, wider than long, bearing two or more enlarged spine bases; apparent adambulacral spines elongate, conical. Circumorals robust, branching radially to enclose a podium; remainder of mouth frame not available.

Etymology.-The species name recognizes the many contributions of Frederick H.C. Hotchkiss to the paleontology of the Asterozoa and other echinoderms, including securing the holotype of D. hotchkissi.

Remarks. - The type species of Delicaster, D. enigmaticus, was assigned to Neopalaeaster when described by Kesling (1967), its taxonomic positioning considered in more detail by Blake (2018). Many ossicles are grooved in the single specimen of $D$. hotchkissi, but grooving is irregular in expression and orientation, indicating that they were produced by an unfortunate initial preparation technique using a wire brush. The only available specimen of D. hotchkissi documents some of the ambiguities resulting from the limitations of fossilization that are encountered in the interpretation of ancient asteroids; for the D. hotchkissi specimen, preservation of many ossicles appears good, and partial ossicular displacement has helped to expose positioning and morphology of many, yet the very disruption that exposed some ossicles also disrupted and obscured others, including those of the disk interior (Fig. 3.1, 3.3). Data available for Delicaster enigmaticus and D. hotchkissi differ in important ways, the emended generic diagnosis reflecting known taxon differences as constrained by incomplete data sets, the difficulties impairing taxon comparison and rendering compilation of comparative data matrices for phylogenetic analyses problematic.

The disk of the D. hotchkissi specimen was flattened during preservation, now appearing broader than likely in life. Although ossicles are disrupted, arm shape is indicated by marginal shape and positioning of ambulacrals and adambulacrals. Unlike the $D$. enigmaticus type (Fig. 4.10), only a few apparent primary circlet ossicles remain in the D. hotchkissi specimen, these appearing similar to those of $D$. enigmaticus, but now displaced. The madreporite is known only for $D$. hotchkissi, its apparent dorsal disk positioning typical of permasterids.

Enlarged dorsal arm ossicles are found in many asteroids similar to D. hotchkissi whereas presence of only small arm abactinals was important to the original diagnosis of Neopalaeaster enigmaticus by Kesling (1967). Although no clearly recognizable dorsal arm ossicles remain in the D. hotchkissi specimen, indirect lines of argument favor absence of enlarged ossicles in this species as well; better-preserved arm intervals are complete enough as to suggest that were enlarged ossicles originally present between and bracing and braced by the marginals, at least a few would be expected to have been preserved, whereas and in contrast, flesh enclosing a field of 
many small ossicles would be more readily subject to rapid decay and concomitant ossicular loss. Further, apparent tilting of dorsal edges of a few marginals argues a dorsal arm interval of comparatively little resistance, such as is likely if only small ossicles were present during life.

The disruption of the disk allowed preservation and exposure of a few circumorals in the D. hotchkissi, these not available for $D$. enigmaticus, whereas MAO are available only for D. enigmaticus. Similarities of overall form and ossicular expression, the latter including presence of upright, rectangular, plate-like arm marginals, robust, T-shaped ambulacrals with well-developed medial podial pores, and the unfortunately limited available data on the dorsal skeleton, enables assignment of $D$. enigmaticus and $D$. hotchkissi to a single genus.

Delicaster hotchkissi differs from the type species $D$. enigmaticus in presence of a comparatively robust skeletal development, particularly recognizable in expression of the marginal series. Although overall shape and orientation of marginal ossicles of the species are similar, marginals of $D$. hotchkissi lack the large spine bases of D. enigmaticus, and instead the more dorsal margins of the outer surfaces are pustulate, the pustule field gradually terminating ventrally. Below the prominent pustules, the ossicular surface appears textured and perhaps suggestive of fine pustules, but a similar surficial expression on the inner ossicular surfaces indicates that the texture represents original skeletal meshwork. Shape and positioning of the axillary differ between the two species.

\section{Significance of the new occurrences}

Comprehensive taxonomic interpretation of most fossil asteroid species is problematic because specimens are generally few, and those that are found typically are incomplete. Paleozoic asteroids are further difficult because closely related extant exemplars are not available. The new taxa here aid understanding of variation among Paleozoic asteroids at lower taxonomic levels.

Sertulaster $\mathrm{n}$. gen. is close to the previously described Eriaster, the latter differing primarily in the presence of supplemental ossicular series in a geologically older taxon. The single known specimen of Eriaster also is smaller than any of the available specimens of Sertulaster, and therefore proliferation of ossicular series was not directed toward size increase in any simple manner. Sertulaster and Eriaster combine to document Ordovician intrafamilial variation suggested to be analogous with that found in extant Ophidiasteridae or Goniasteridae.

Delicaster morphology is relatively distinctive, and $D$. hotchkissi n. sp. is readily assigned to Delicaster, the genus previously known from a single recognized species. The new species helps delineate range of variation within the laterPaleozoic Permasteridae; later-Paleozoic records are limited, even by standards of the Asteroidea. The two Delicaster species argue differing selective pressures within a single generic clade. Concomitant constructional ranges and uncertainties for extant genera include treatment of Luidia Forbes, 1839; Döderlein (1920) recognized four supergeneric 'groups' and eight subgenera for 46 species, whereas Fell (1963) recognized the subgenera of Döderlein at the generic level.

\section{Acknowledgments}

F.H.C. Hotchkiss purchased the holotype of Delicaster hotchkissi, the specimen subsequently donated to the Yale Peabody Museum by the Marine and Paleobiological Research Institute (MPRI), the YPM making the specimen available for study. T. Guensburg and F.H.C. Hotchkiss reviewed the manuscript, and E. Currano and S. Zamora provided editorial services. We are indebted to all.

\section{References}

Armstrong, D.K., 2000, Paleozoic geology of the northern Lake Simcoe area, south-central Ontario: Ontario Geological Survey Open File Report 6011, $34 \mathrm{p}$.

Blake, D.B., 2013, Early asterozoan (Echinodermata) diversification: A paleontologic quandary: Journal of Paleontology, v. 87, p. 353-372.

Blake, D.B., 2014, Two Ordovician asterozoans (Echinodermata) of problematic affinities: Journal of Paleontology, v. 88, p. 1163-1173.

Blake, D.B., 2018, Toward a History of the Paleozoic Asteroidea (Echinodermata): Bulletins of American Paleontology, no. 394, 96 p.

Blake, D.B., and Elliott, D.R., 2003, Ossicular homologies, systematics, and phylogenetic implications of certain North American Carboniferous asteroids: Journal of Paleontology, v. 77, p. 476-489.

Blake, D.B., and Guensburg, T.E., 2005, Implications of a new Early Ordovician asteroid (Echinodermata) for the phylogeny of Asterozoans: Journal of Paleontology, v. 79, p. 395-399.

Blake, D.B., and Guensburg, T.E., 2015, The class Somasteroidea (Echinodermata, Asterozoa): Morphology and occurrence: Journal of Paleontology, v. 89 , p. $465-486$.

Blake, D.B., and Hagdorn, H., 2003, The Asteroidea (Echinodermata) of the Muschelkalk (Middle Triassic of Germany): Paleontologische Zeitschrift, v. 77 , p. 23-58.

Brookfield, M.E., and Brett, C.E., 1988, Paleoenvironments of the MidOrdovician (Upper Caradocian) Trenton limestones of southern Ontario, Canada: Storm sedimentation on a shoal-basin shelf model: Sedimentary Geology, v. 57, p. 75-105.

David, B., and Mooi, R., 1996, Embryology supports a new theory of skeletal homologies for the phylum Echinodermata: Comptes Rendus Académie des sciences 3, Sciences de la vie/Life Sciences, v. 319, p. 577-584.

David, B., and Mooi, R., 1998, Major events in the evolution of echinoderms viewed by the light of embryology, in Mooi, M., and Telford, M., eds., Echinoderms: San Francisco, Rotterdam, A.A. Balkema, p. 21-28.

Döderlein, L., 1920, Die Asteriden der Siboga-Expedition 2: Die Gattung Luidia und ihre Stammesgeschichte: Siboga Expedition, Monographie 46b, p. $193-293$.

Fell, H.B., 1963, The phylogeny of sea-stars: Philosophical Transactions of the Royal Society, London B, v. 246, p. 381-435.

Forbes, E., 1839, On the Asteriadae of the Irish Sea: Memoirs of the Wernerian Natural History Society of Edinburgh, v. 8, p. 113-129.

Holland, S.M., and Patzkowsky, M.E., 1996, Sequence stratigraphy and longterm paleoceanographic change in the Middle and Upper Ordovician of the eastern United States: Geological Society of America Special Papers, v. 306, p. 117-130.

Hotchkiss, F.H.C., 1993, A new Devonian ophiuroid (Echinodermata: Oegophiurida) from New York State and its bearing on the origin of ophiuroid upper arm plates: Proceedings of the Biological Society of Washington, v. 106, p. $63-84$.

Kesling, R.V., 1967, Neopalaeaster enigmaticus, new starfish from Upper Mississippian Paint Creek Formation in Illinois: Contributions from The Museum of Paleontology, The University of Michigan, v. 21, p. 73-85.

Kesling, R.V., 1969, Three Permian starfish from Western Australia and their bearing on revision of the Asteroidea: Contributions from The Museum of Paleontology, The University of Michigan, v. 22, p. 361-376.

McKnight, D.G., 1975, Classification of somasteroids and asteroids (Asterozoa: Echinodermata): Journal of the Royal Society of New Zealand, v. 5, p. $13-19$.

Miller, S.A., 1889, North American Geology and Palaeontology for use of Amateurs, Students, and Scientists: Cincinnati, Western Methodist Book Concern Press, $664 \mathrm{p}$

Mooi, R., and David, B., 1998, Evolution within a bizarre phylum: Homologies of first echinoderms: American Zoologist, v. 38, p. 965-974.

Mooi, R., and David, B., 2000, What a new model of skeletal homologies tells us about asteroid evolution: American Zoologist, v. 40, p. 326-339. 
Mooi, R., and David, B., 2008, Radial symmetry, the anterior/posterior axis, and echinoderm Hox genes: Annual Review of Ecology, Evolution, and Systematics, v. 39, p. 43-62.

Mooi, R., David, B., and Marchand, D., 1994, Echinoderm skeletal homologies: Classical morphology meets modern phylogenetics, in David, B., Guille, A., Féral, J-P., and Roux, M., eds., Echinoderms through Time: Rotterdam, A.A. Balkema, p. 87-95.

Shackleton, J.D., 2005, Skeletal homologies, phylogeny and classification of the earliest asterozoan echinoderms: Journal of Systematic Palaeontology, v. 3, p. 29-114.

Spencer, W.K., 1914-1940, The British Palaeozoic Asterozoa: Palaeontographical Society of London Monograph, pts. 1-10 (for 1913-1940), 540 p

Spencer, W.K., 1951, Early Palaeozoic starfish: Philosophical Transactions of the Royal Society, London B, v. 235, p. 87-129.

Spencer, W.K., and Wright, C.W., 1966, Asterozoans, in Moore, R.C., ed. Treatise on Invertebrate Paleontology, Part U, Echinodermata, Volume 3
(1): Boulder, Colorado, and Lawrence, Kansas, Geological Society of America and University of Kansas Press, p. U4-U107.

Sproat, C.D., Jin, J., Zhan, R.B., and Rudkin, D.M., 2015, Morphological variability and paleoecology of the Late Ordovician Parastrophina from eastern Canada and the Tarim Basin, Northwest China: Palaeoworld, v. 24, p. $160-175$.

Villier, L., Brayard, A., Bylund, K.G., Jenks, J.F., Escarguel, G., Loivier, N., Stephen, D.A., Vennin, E., and Fara, E., 2017, Superstesaster promissor gen. et sp. nov., a new starfish (Echinodermata, Asteroidea) from the Early Triassic of Utah, USA, filling a major gap in the phylogeny of asteroids: Journal of Systematic Palaeontology, v. 16, p. 395-415. https:// doi/10.1080/14772019.2017.1308972.

Accepted 28 July 2018 